\title{
ABSTRACTS AND REVIEWS
}

Richard L. Sandwick. How to Study and What to Study. New York: D. C. Heath \& Co., 1915. Pp. 170.

The first part of the book is a simple presentation to "younger students" of a number of "principles of effective study." On the whole this part ought to be of rare value to students about to enter high school or even to those in the eighth grade. However, a few assertions of "principles" seem pernicious. Chapter VI is a blot on the book: "Study aloud or with lips moving, in order (1) to strengthen attention and hold the mind upon the work in hand, and (2) to strengthen the memory by providing more mediums for recall." (Page 41.) This does not accord with the writer's foreword: "As I have kept pace with the slowly developing literature of educational psychology." Modern literature on the higher thought process, on silent reading, etc., even in their slowness have outrun this ardent advocate of studying aloud. In the light of the increase in school study and relative decrease in home work perhaps most pedagogues would prefer not to borrow China's scheme of study.

The second half of the book on What to Study and How aims to guide in "a reasonable choice of studies, or strengthen your purpose when a choice has already been made." If the author is taken at his word a majority of high school students may feel obliged to study Latin in order to "increase the power to read and understand English," to spell, and "to appreciate the civilization of the Roman peoples." Some of these students, especially if they get no farther than the high school, may discover that they have chosen a long and rugged road to Rome unless they "trot" with "free translations."

The author maintains that to study history is to induce right personal conduct since good and bad get their due rewards. The "persistent Washington . . . wrings victory from defeat." "The cruel tyrant . . . falls by the avenger's knife." The student that sets out to find these statements true soon would be hopelessly confused by contradictions. History is replete with evidence that the villain does not always get his dues nor the benefactor his reward. Rather, as most texts fail to show, individual conduct of the monarch or the slave earns a reward which is paid to and by succeeding social 
generations. The author ignores a still better reason for studying history, namely, to nullify human prejudices and to foster human brotherhood. Designed for adolescents who respond rather readily to appeals for social service, this book unduly emphasizes the breadand-butter end of learning.

In spite of other obvious defects there are so many good things in this concise, attractive, clearly-written, well-bound little volume that it could be used with profit as a text from which high school pupils could be given some specific directions in the art of study. It should be of special value to the teacher.

Brooklyn Training School for Teachers.

Garry C. Myers.

Calvin N. Kendali and George A. Mirick. How to Teach the Fundamental Subjects. Boston: Houghton Mifflin Co., 1915. Pp. ix, 329. \$1.50.

The term "fundamentals" in education, which originally had reference to the formal subjects only, has come to have less and less significance as some of the older content subjects have gradually found their way into this favored group.

In their discussion in this book, the authors have not only treated as "fundamentals" the formal subjects of English (which includes reading, common speech, composition, grammar, spelling, and penmanship) and mathematics, but to these have added history, geography, and civics, and then, as if to destroy the usefulness of the term "fundamentals" entirely, have devoted one of their best chapters to the subject of teaching hygiene. Not the anatomical, text-book kind of two decades ago, but the kind which leaves the child with such definite ideas and habits as will make a difference in his own health, and in the health of the community. Such an inclusive use of the term "fundamentals" should help in breaking down in school practice, the traditional barrier between the formal on the one hand, and the concrete and useful on the other.

The book is divided into five chapters: The point of view; English; mathematics; geography, history, civics; and hygiene; and no one of the topics has been given an undue amount of space. It is directly addressed to teachers and supervisors, and impresses one as having been written from the standpoint of definite problems, which have been met with in the schoolroom, rather than from the standpoint of the pedagogy of the school subjects. The scientific principles upon 